Litinfinite Journal

ISSN: 2582-0400 [Online]

CODEN: LITIBR

Vol-1, Issue-1 ( $2^{\text {nd }}$ July, 2019)

Page No: 41-46

DOI: 10.47365/litinfinite.1.1.2019.41-46

Section: Article

\title{
Such a Long Journey: A tale of the Indian Parsis and Indian Politics
}

\section{Ipsita Seth Biswas}

Assistant Professor

Amity Institute of English Studies and Research,

Amity University, Kolkata, West Bengal, India.

Mail Id: ipsita_seth14@yahoo.co.in

\begin{abstract}
This paper presents two prominent themes of the novel Such a Long Journey. Parsis in India are a demographically and socially declining community. They once enjoyed a higher social status, however, with passing time they are reduced to second class citizens. This fact remains a major dissatisfaction for them. They, at the same time, take immense pride in their cultural identity. The various rituals related to their day to day chores and even during death are very different from the others'. This gives them a separate ethnic identity, which they cherish. A depiction of the lives, customs and displeasure of the Parsis living in India is highlighted in this write up. Politics too remains another noteworthy theme which is discussed here. The political setback centrally and locally, as perceived by the common mass, has a direct impact on their wellbeing. The scheming government at the center shudders the lives of the protagonist and his close ones. At the same time its incapability to handle situations of war or performing the duties towards the citizens, leave them in contempt. The inertness of the municipality too in doing its important duties leave the residents disgusted. Both these masterfully intertwined themes are studied in this research paper.
\end{abstract}

Keywords: Parsi, Parsi Community, Indian politics.

The growth of Indian writing in English is exceptional. From the likes of Mulk Raj Anand, R. K. Narayan, Jayant Mahapatra to Arundhati Roy, Salman Rushdie, Shashi Deshpande etc., literature lovers have tasted India in its bare reality. As soon as any writer's creativity is out in black and white, the writer gets drawn under the spot-light. And Rohinton Mistry is no exception to it. Such a Long Journey (1991), which happens to be Mistry's debut novel, acquaints us with how brilliantly he uses and sometimes experiments with his language. The accent he uses gloriously to tell his tale and the description of the piquant reality of the common man getting entangled in the socio- political issues of the society as well as the country is absolutely crafty. Considered a masterpiece, Such a Long Journey, heralds Mistry's arrival as a gifted novelist. This paper delves into two such dominant themes, which shape the entire novel. First, the declining social stature of Parsis in post independent India that remains one of the gravest concerns for the Parsi community. Their dissatisfaction is beautifully portrayed through an internal analepsis technique. Second, politics that strikes the characters' lives stands as another major theme in the novel. The manner in which the political scenario happens to directly have an impact the common mass is equally laudable. 
Rohinton Mistry's works instantly draw our attention towards the Parsi Community, for the Parsis and their culture are one of the most dominating aspects of Mistry's novels. The Parsis are a small, united and religious community in India. They are followers of Zoroastrianism, the faith originally propagated by the prophet Zoroaster between 1500 B.C. and 600 B.C. Parsis are basically, the natives of Iran (ancient Persia). Their ancestors fled due to Islamic persecution during 800 A.D. and settled in India. With thirteen hundred years on Indian soil, the Parsis have lived the ups and downs of life. They embraced modern education and became successful in industry and commerce. They enjoyed good relations with the British colonizers and surged ahead to become the most westernized of all Indian communities. This not only alienated them from the Indian mainstream, but also cut them off from their own Parsi roots (Bharucha 74). Surely enough independent India had something else in store for them. Their exalted social position was gradually eroded and now they have been marginalized- thought of as a minority group. This contemptuous condition influenced yet another Parsi Diaspora, this time to the West.

Such a Long Journey wove a vivid picture of the Parsi community in India. The culture, customs and their concern for the declining status of their community is well depicted in the novel. According to Jaydipsingh Dodiya, the concern of Parsi community figures prominently in Such a Long Journey. The inhabitants of Khodadad building are representatives of a cross-section of middle-class Parsis expressing all the angularities of dwindling community. The novel also focuses on some customs and rituals of the Parsi community (6). The very opening lines of the novel, effortlessly inserts the reader's mind into the Parsi environment:

The first light of the morning barely illumined the sky as Gustad Noble faced eastward to offer his orisons to Ahura Mazda. The hour was approaching six, and up in the compound's solitary tree the sparrows began to call. Gustad listened to their chirping every morning while reciting his Kusti prayers (SLJ 1).

The kusti or the gridle must be tied with 'Vohu Manik Vastra'- the garment of Vohumana, the good mind. One is not a true Zoroastrian till he or she is invested with sudra and kusti, the two great ambles of their reigion. The religious significance of the kusti could be very well observed during the Morning Prayer done by the protagonist Gustad Noble.

The funeral procession of Gustad's colleague Dinshawji and Gustad's best friend Jimmy Billimoria to the Tower of Silence or Dakhma, throws light on yet another custom of the Parsis. The Tower of Silence is one of the central symbols of the Parsi culture which distinguishes it from other cultures. Whenever death occurs in a Parsi household, a corner of the sick room is washed and a clean sheet is spread. The priest lights the sacred fire with sandalwood and chants prayers to soothe the departing soul. A close relative or a dear friend whispers "the Yatha Ahu Varyo, five times, and Ashem Vahoo, three times" (336). Then two men take bath, recite the kusti, put on clean white clothes and enter in the room holding a piece of white tape, to withstand any infection from the corpse. The whole body is covered with a white shroud except the face. Three kashas or circles are drawn round the corpse. Then the sag-did (sag-dog; did-sight) ritual takes place. A dog is brought and made to look at the body to ensure that there is no life. 
Litinfinite Journal

ISSN: 2582-0400 [Online]

CODEN: LITIBR

Vol-1, Issue-1 ( $2^{\text {nd }}$ July, 2019)

Page No: 41-46

DOI: 10.47365/litinfinite.1.1.2019.41-46

Section: Article

After having done the initial ceremony for the dead the nassasalers (professional pallbearer) carry the body to the Tower. The men follow in "twos or threes, linked by white handkerchiefs" (252). Only the nassasalers are allowed inside the Tower, where they keep the dead body on the outermost of three concentric stone circles. Then with special hooked rods tear off the cloth to make the body naked for the vultures, who feed upon it. In the meantime outside the Tower the men offer prayers to the dead's ascending soul. Then they wash their hands and faces, do their kustis and return. In order that the water, the fire and the earth are not made unclean, the Parsis prefer being eaten up by vultures, unlike the Hindus, Muslims or Christians, which surely provide them a separate identity.

Another significant aspect is also prevalent in Mistry's maiden novel which is the concern of the Parsis for their declining status. The Parsis were once the masters of banking but the present situation is such that they have lost all their glory. Moreover, with the advent of the Shiv Sena in Maharashtra government, their condition has even more deteriorated. They hold the government responsible for their demotion to second-class citizens. They never miss a chance to accuse the government to show their contempt. The existing threats to the Parsi family and community are very clearly depicted by Mistry. According to Dodiya, Rohinton Mistry:

Presents his community through the different narratives of his characters who invariably express their concern for their community and the changes that affect their community. Since their fate is bound up with the fate of their community, their stories tend to be the stories of their community. By centralizing their community in their narratives, they preserve and protect themselves and thus they throw light on the existing facts (93).

Though, the novel is enveloped with the essence of the Parsi religion, Mistry narrates a story rich in subject matter, characterization and symbolism. Set in India, the novel highlights the chaotic times of 1971, during which India and Pakistan went to war over the liberation of East Pakistan, now, Bangladesh. The political context creates certain unavoidable circumstances, thus engulfing the protagonist, his family members and friends.

Mistry has a firsthand knowledge about the political history of India. Having spent twentythree years on the Indian soil, he has learnt a lot about the socio-political background of our country. The Indira Gandhi Government of 1970's was the cause of much dissatisfaction, especially for the Parsis, and hence corruption, politically motivated schemes, political decisions, common people's sufferings, caste problem, etc. occupy considerable space in the novel. Mistry skilfully parallels public events involving Indira Gandhi with the misfortunes of the novel's principal characters. The chief theme is the Nagarwala Conspiracy case in which the Prime Minister gets directly involved. The fictional enactment of this case brings turmoil in the life of the protagonist, Gustad Noble.

There are numerous references to the wars or the events related to war against the neighbouring countries. Events such as the 1948 Pakistan invasion of Kashmir, Indo-China war in 1962, Indo-Pak war during 1965 and 1971 and the birth of Bangladesh are knitted well 
within the story. Year 1962 was both a remarkable and a dreadful year for India as well as Gustad. He saw the birth of his youngest daughter Roshan and, in the same year, he met with an accident in an attempt to rescue his son. This broke his hip, which left him limping for the rest of his life. The year 1962 also experienced the Indo-China clash in which India saw, "such a humiliating defeat, everywhere people talking of nothing but the way Chinese had advanced as though the Indian army consisted of tin soldiers" (9). This thrashed Nehru's utopia and his slogan 'Hindi-Chinese bhai-bhai' proved wrong. The common man rated this as Nehru's incapability to handle political disturbances, unlike Lal Bahadur Shastri, whose proficiency was seen during "the twenty one day war with Pakistan in which he fared better than Nehru had in the War with China" (114).

Apart from this, Nehru was entangled in family controversy with his son-in-law, Feroz Gandhi. He was more interested in securing a place for his worthy daughter as his successor, ceasing to be a defender or champion of the downtrodden. On the other hand Lal Bahadur Shastri, the man who was "short in height but tall in brains" (114) emerged as a hero. The people found a new ray of hope with his coming to power. They expected a better and brighter future under his administration. Quite naturally, his sudden demise raised several fingers of suspicion in several directions from Pakistanis to Russians to the rotten Indian politics. Consequently when Indira Gandhi came to power after the death of Shastri, corruption reached its peak.

The fictional enactment of the Nagarwala case by Gustad's estranged friend Major Jimmy Bilimoria clearly hints at Mistry's intention to bring to light, the pungent political issues. Gustad came face to face with an entirely new story, when he met his best friend Jimmy at the hospital. Jimmy narrated to him the entire fact of how he was trapped and was made guilty by the master-mind PM. Under the numbing clutches of the injections he told the truth with great effort. The truth was that he got an exciting offer from the Prime Minister's Office to join the Research and Analysis Wing. He was asked to join as a management consultant. But to his utter surprise, Indira Gandhi was using RAW like "her own private agency. Spying on opposition parties, ministers... anyone. For blackmail" (270). Jimmy felt sick at this and he applied for transfer.

Meanwhile the condition in East Pakistan had deteriorated. Elections, civil disobedience, slaughters, blood-sheds and what not! Jimmy was right away interested to help the guerrilla movement and so was again called by the Prime Minister's office for an interview. There he was given the charge of training and supplying the Mukti Bahini. But "Money was the main thing for Mukti Bahini. Without money, no supplies, no explosives, no guns... nothing. We needed a regular allocation, a budget" (272). Hearing this Indira Gandhi said that she will talk to the chief cashier to lend sixty lakh rupees to a Bangadeshi Babu and instructed Jimmy, "Next morning go to State Bank, meet chief cashier, ask for sixty lakh rupees... don't tell chief cashier name or RAW identity. Only Bangladeshi Babu... come for sixty lakh" (272). In this manner he withdrew the sixty lakh rupees from the State Bank disguised as a Bangladeshi Babu.

Indira Gandhi had made certain plans to protect herself and trap Jimmy. She being a political leader had many enemies and if her enemies found that the enormous amount of money was 
Litinfinite Journal

ISSN: 2582-0400 [Online]

CODEN: LITIBR

Vol-1, Issue-1 ( $2^{\text {nd }}$ July, 2019)

Page No: 41-46

DOI: 10.47365/litinfinite.1.1.2019.41-46

Section: Article

taken out from the bank at her request, they could use this information against her. So she asked Jimmy to write a confession that he had imitated her voice because he needed the money to help Mukti Bahini. Jimmy agreed without thinking much about the consequences. It was later when he himself went to the camp for an inspection, he found the truth. He was shocked at their condition, "Ragged condition... bare feet, torn clothes, no helmets. A few had guns... rest drilling with sticks, branches. Something terribly wrong..." (278). What happened to the new financing? Where has all the money gone which was withdrawn for this purpose? Such questions rocked his mind and stunned his senses. He made investigations and found out that the money was seized by the Prime Minister's office and sent to her private account. The money was kept for her personal use.

This made Jimmy restless and he decided to take out ten lakh rupees from the account and sent it to Gustad, for if the Prime Minister can benefit herself from the money then why not him and his friends. But he was wrong to think so. A case was made against him based on his confession. All they wanted was the missing ten lakh. Therefore Jimmy asked Gustad to return the ten lakh rupees. After the money was returned he was released and transferred to a hospital for treatment as his health worsened due to the ill-treatment in jail. In this manner he was tricked and trapped cleverly before being gulped by the political schemes.

Such a Long Journey has also attacked Indira Gandhi for the nationalization of banks, for her encouragement to make a separate Maharashtra state that caused bloodshed and riot, and for her creation of Shiv Sena to divide people on class basis. Indira Gandhi's idea to nationalize the banks was loathsome to the Parsis as earlier Parsis were considered the kings of banking and were respected for the same. But nationalization had spoiled everything. Gustad says, "Nowhere in the world has nationalization worked. What can you say to idiots" (38). Mrs. Gandhi's decision to give a separate identity to Maharashtra resulted in rioting and bloodshed thus destroying the peace of the nation. With the formation of Shiv Sena the conditions worsened. "The Sena raised the bogey of "the other"- the religious other, the Muslim; the linguistic other, especially Tamil speakers; and the regional other, those who came from other parts of India" (Bharucha 28). Amidst such decision makings the Parsis were the worst sufferers for they had lost the authority and status of which they were used to before independence. Being demoted to second-class citizens their future became unpredictable and possibly blank.

Along with the corrupted center, the Municipality too is shown as a nuisance for the common man. The municipality is shown as not paying heed to people's problems and hence its entire mending works remain pending. The petitions and letters of complaint against overflowing sewers, broken water-pipes, pot-holed pavement, rodent invasions, bribe extracting public servants, uncollected hills of garbage, open manholes, shattered street lights etc. are consistently ignored. The corruption at the center extended its branches to the periphery as the Municipality too is shown as a nuisance for the common mass. The incapability to uplift and strengthen the nation remains a bitter truth. This is the reason why politics turns out to be a debatable issue in most of the chapters of the novel.

Rohinton Mistry proves himself to be an expert in delineating the middle-class and lower middle-class Parsi families. His fiction ranges from the 1960s, through the Emergency, to 
Litinfinite Journal

ISSN: 2582-0400 [Online]

CODEN: LITIBR

Vol-1, Issue-1 ( $2^{\text {nd }}$ July, 2019)

Page No: 41-46

DOI: 10.47365/litinfinite.1.1.2019.41-46

Section: Article

contemporary India and shows how the political upheavals hamper the daily life of the common mass. With great subtlety he describes the routine of the people, their daily chores from morning to night, constantly safeguarding it from the 'larger-than-life' concept. His protagonists are unlike Shakespearean heroes who are full of zeal, vigour, and courage; who belong to the highest level of society and make their destiny themselves. Mistry's characters are very common, down to earth, easily moved by emotions and are governed by the incidents happening around them. Pramod K. Nayar gives a similar opinion when he writes the foreword to The Novels of Rohinton Mistry: A Critical Study. He says, "Mistry's realism enables the smooth expression of, the everyday and the common which assumes paramount importance. Mistry's characters are believable in their very ordinariness"(viii).

Though not a prolific writer, Rohinton Mistry is yet formidable and one of a kind. What remains noteworthy is the subject of all his writings that highlight life of Parsis in Bombay. Mistry successfully conveys the common human issues of spiritual questions, alienation, fear of death, family problems and economic hardships. However, hope prevails in these stories, as Mistry's compassionately drawn characters survive and work through difficult circumstances towards a brighter future. His novels have helped him in earning a distinct place in the annals of the post independence Indian English fiction. His eminence as a novelist lies in his endeavours to narrate his community, his country and crises of humanity in fictional terms, in a manner in which only Rohinton Mistry can do.

\section{Works cited}

i. Bharucha, Nilufer E. "The Parsi Voice in Recent Indian English Fiction: An Assertion of Ethnic Identity." Indian-English Fiction. 1980-90: An Assesment. Nilufer E. Bharucha, and Vilas Sarang, editors. Delhi: B.R. Publishing Corporation, 1994.

ii. Dodiya, Jaydipsingh. "The Parsi Community in Such a Long Journey." The Fiction of Rohinton Mistry: Critical Studies. Jaydipsingh Dodiya, editor. New Delhi: Prestige books, 1998.

iii. Mistry, Rohinton. Such a Long Journey. New York: Vintage International, 1992.

iv. Nayar, Pramod K. "The Quotidian Imaginary: The Fiction of Rohinton Mistry." The Novels of Rohinton Mistry: Critical Studies. Jaydipsingh K. Dodiya, editor. New Delhi: Sarup and Sons, 2004. 